\title{
Paleoclimatic interpretation of the early Late-glacial glacier in the Gschnitz valley, central Alps, Austria
}

\author{
Hanns Kerschner, ${ }^{1}$ Susan Ivy-Ochs, ${ }^{2,3}$ Christian Schlüghter, ${ }^{3}$ \\ ${ }^{1}$ Institut für Geographie, Universität Innsbruck, Innrain 52, A-6020 Innsbruck, Austria \\ ${ }^{2}$ Institut für Teilchenphysik, ETH - Hönggerberg, CH-8093 Zürich, Switzerland \\ ${ }^{3}$ Geologisches Institut, Universität Bern, CH-3012 Bern, Switzerland
}

\begin{abstract}
The former glacier at the type locality of the "Gschnitz Stadial" of the Alpine Late-glacial chronology is interpreted from a paleoglaciological and paleoclimatological point of view. The equilibrium-line altitude, ice flux through selected cross sections and mass-balance gradients are calculated from reconstructed glacier topography. They are used to determine total net ablation and accumulation and precipitation under the assumption of steady-state. The former temperature at the ELA and temperature change is estimated using various glacier-climate models. Precipitation was less than one-third of today's values, and summer temperature was roughly $10^{\circ} \mathrm{C}$ lower than today. The climate during the Gschnitz Stadial appears to have been cold and continental, and was more similar to full glacial conditions than to the Younger Dryas climate in the Alps. This is further evidence for an older age of the Gschnitz Stadial.
\end{abstract}

\section{INTRODUCTION}

Late-glacial glaciers may provide valuable quantitative information about the climate during their existence (Maisch and Haeberli, 1982; Kerschner, 1985; Maisch, 1987). If their surface geometry can be reconstructed with a reasonable degree of accuracy, it is possible to derive various glaciological parameters which can be interpreted climatically (e.g. Maisch and Haeberli, 1982; Haeberli and Penz, 1985). Among these parameters are the past equilibrium-line altitude (ELA), ELA depression $(\Delta \mathrm{ELA})$, basal shear stress $(\tau)$ and mass balance gradients $(\partial b / \partial z)$. In this paper, the former glacier at the type locality of the "Gschnitz Stadial" of the Alpine Lateglacial chronology is interpreted from a paleoglaciological and paleoclimatological point of view. It may give some valuable insight into the climatic conditions in the Alps during an early phase of the Alpine Late-glacial, for which paleoclimatic proxy information from other sources (e.g. lake sediments, pollen analysis) is largely absent.

The complex of lateral and end moraines in the Gschnitz valley, near the village of Trins (Pichler, 1859; Kerner von Marilaun, 1890), about $30 \mathrm{~km}$ to the southwest of Innsbruck (Fig. 1) was chosen by Penck and Brückner (1901/1909) as the type locality of the Gschnitz Stadial of the Alpine Lateglacial chronology. Since then, various authors have studied the glacial geomorphology of the Gschnitz valley (e.g. Paschinger, 1952; Mayr and Heuberger, 1968), defining and redefining the Late-glacial chronology of the eastern Alps in general and that of the Gschnitz valley in particular (cf. Kerschner, 1986). Today, the moraine at Trins is again considered the type locality of the Gschnitz Stadial (Mayr and Heuberger, 1968; Patzelt and Sarnthein, 1995).

Moraines of the Gschnitz Stadial, as presently defined, have been found elsewhere in the Alps (e.g. Mayr and Heuberger, 1968; Patzelt, 1975; Gross and others, 1977; van

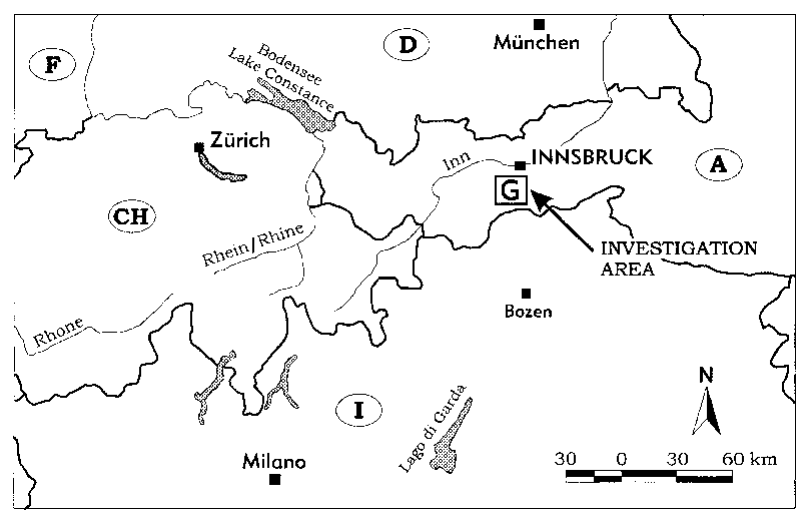

Fig. 1. Location of Gschnitz valley $(G)$ in the central Alps.

Husen, 1977; Maisch, 1987). Minimum radiocarbon ages suggest they were deposited during the Oldest Dryas. They show that large parts of the central Alps were already icefree and only covered by local glaciers some time before the beginning of the Late-glacial Interstadial (BøllingAllerød). No reasonable minimum ages could be obtained for the type locality, but recent surface-exposure dating $\left({ }^{10} \mathrm{Be},{ }^{26} \mathrm{Al}\right)$ of the end moraine (Ivy-Ochs and others, 1997; see Ivy-Ochs and others 1996, 1998 for the sampling and dating methodology) suggests a preliminary age of about 15 kyr BP for its deposition.

\section{GEOMORPHOLOGY}

A prominent end moraine occurs in the Gschnitz valley close to the village of Trins at an altitude of $1200 \mathrm{~m}$ a.s.l., marking the end of a former local glacier. The lateral moraines are well preserved on both sides of the valley (cf. Kerner von Marilaun, 1890; Paschinger, 1952) for a distance of more than $3 \mathrm{~km}$ up to an altitude of $1410 \mathrm{~m}$. From the morphology of the 

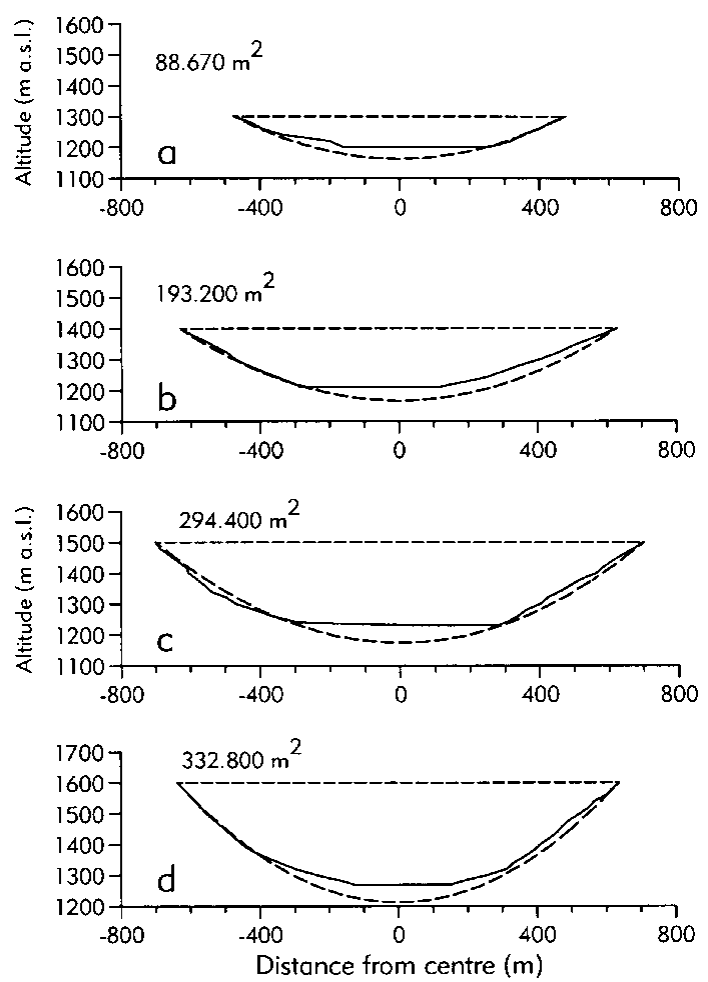

Fig. 2. Cross-sections of the lower part of Gschnitz valley. Solid lines represent the actual topography, dashed lines the parabolic cross-sections. Letters a-d refer to the position of cross profiles in Figure 3. Surface areas of the parabolic cross profiles are indicated in upper left.

moraines it can be concluded that the lefthand part of the former glacier tongue, below $1300 \mathrm{~m}$ (about $1 \%$ of the glacier surface), was covered with rockfall debris. Above the village of Gschnitz, 6-6.5 km from the end moraine, remnants of moraines at an altitude of $1520-1540 \mathrm{~m}$ can be traced to the lateral moraines downvalley.

The valley is almost straight and its width varies only slightly for the entire length of the former glacier tongue (about $12.5-13 \mathrm{~km}$ ). The lower parts of the valley walls are covered with scree slopes, morainic material and alluvial cones from small tributaries. Wherever bedrock is exposed, the cross-section is almost perfectly parabolic (Fig. 2). Between the end moraine and the present-day end of the public road at Gasthaus Feuerstein, the valley floor rises for $100 \mathrm{~m}$ over a distance of $9 \mathrm{~km}(1.1 \%)$. From there to Lappones Alm it is somewhat steeper (7.6\%). Farther upvalley, a step leads $400-500 \mathrm{~m}$ up to the cirque areas, which are presently glacierized (Fig. 3). The surrounding peaks are in the order of 2800-3200 m a.s.l. The comparatively simple

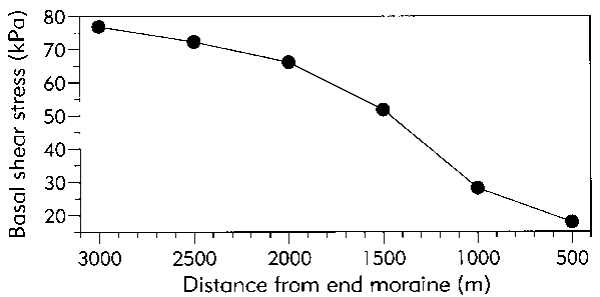

Fig. 4. Basal shear stress at the glacier tongue.

morphology of the lower part and the large number of preserved moraines makes the Gschnitz valley well suited for reconstructing a glacier tongue.

\section{REGONSTRUGTION OF GLAGIER TOPOGRAPHY}

Due to the favourable morphological situation, the surface topography of the glacier tongue can be reconstructed with a high degree of accuracy.

As a first step, the basal shear stresses in the lowest $3 \mathrm{~km}$ of the tongue are calculated as

$$
\tau=\rho g h \sin \alpha f
$$

with $\rho$ the density of glacier ice $\left(900 \mathrm{~kg} \mathrm{~m}^{-3}\right), g$ the acceleration due to gravity $\left(9.81 \mathrm{~m} \mathrm{~s}^{-2}\right), h$ the thickness of the glacier at its centre-line, $\alpha$ the slope of the glacier surface and $f$ the shape factor for a channel with parabolic cross-section (Nye, 1965). $h$ is calculated from the altitude of the moraine crests assuming a parabolic cross-section for the valley (dashed line in Fig. 2). $\alpha$ is calculated from the lateral moraines over a horizontal distance which is five times the glacier thickness. As the glacier tongue becomes steeper upvalley, the basal shear stress rises from about $18 \mathrm{kPa} 500 \mathrm{~m}$ from the end moraine to $77 \mathrm{kPa} 3000 \mathrm{~m}$ from the end moraine (Fig. 4).

The surface profile between the upper end of the moraines (1410 m a.s.l., km 3.4, Fig. 3) and the point where the bed slope steepens significantly (km 8.3, Fig. 3) was calculated using the theoretical long profile of a glacier tongue (Nye, 1952). Under the assumption of steady-state, it relates glacier length $(x)$ and thickness $(h)$, if the difference between bed slope $(\beta)$ and surface slope $(\alpha)$ is small, as

$$
x=\frac{h_{0}^{\prime}}{\beta^{2}}\left(\ln \frac{h_{0}^{\prime}}{h_{0}^{\prime}-h \beta}\right)-\frac{h}{\beta}
$$

with $h_{0}^{\prime}=\tau^{\prime} / \rho g$ and $\tau^{\prime}=\tau / f$. By connecting the lowest points of the parabolic cross- sections, a bed slope of $0.88 \%$ can be calculated. With $h_{0}^{\prime}=12.8 \mathrm{~m}$, the reconstructed glacier surface passes through the ice-marginal features above the village of Gschnitz. With a shape factor $f=0.68$, as deter-

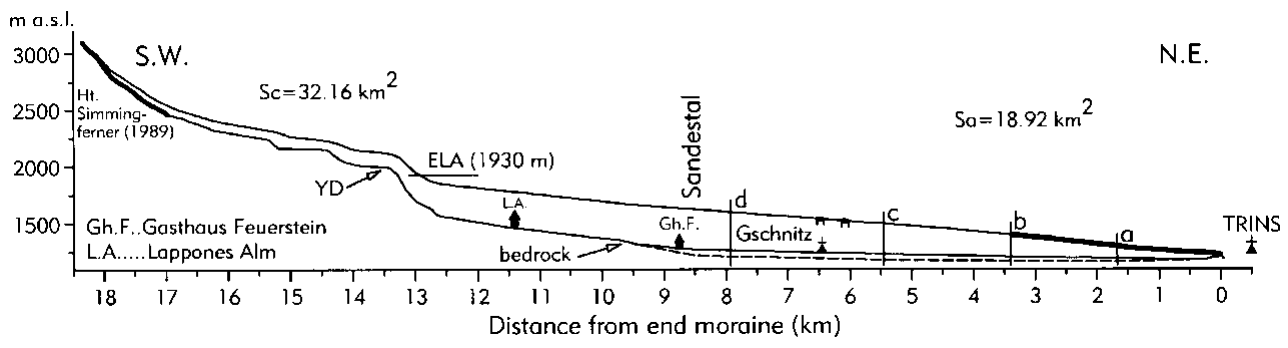

Fig. 3. Long profile of the Gschnitz valley and Gschnitz Stadial glacier. Thick lines at the glacier tongue and above the village of Gschnitz represent preserved moraines. Sc is accumulation area; Sa is ablation area; YD is position of the Egesen Stadial ( Younger Dryas) glacier end. 


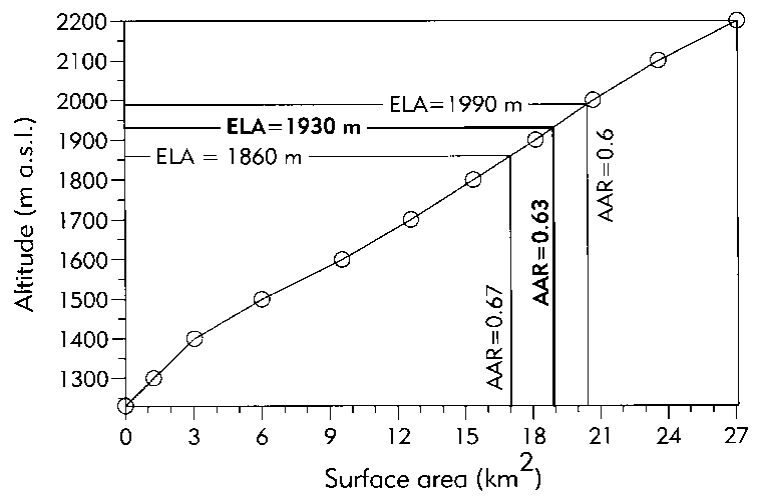

Fig. 5. Area-altitude distribution of Gschnitz glacier tongue and ELAs for different $A A R$ values.

mined from the topography, this is equivalent to a shear stress of $76.8 \mathrm{kPa}$, which is similar to the value further downvalley.

In the upper part of the valley, moraines are missing. Here, the glacier received considerable amounts of ice from the large cirque areas at both sides of the valley and from the Sandestal tributary. Hence, it is reasonable to assume the glacier thickness decreased somewhat upvalley (Fig. 3). At the step, which leads up to the cirque areas, the ice thickness was calculated with a shear stress of $400 \mathrm{kPa}$, as it was typical for the steep part of the Little Ice Age Rhonegletscher (Haeberli and Schweizer, 1988). In the cirque areas, which are very wide compared to the ice thickness, a constant shear stress of $100 \mathrm{kPa}$ was used.

With the help of the long profile, the topography of the glacier tongue was drawn with $100 \mathrm{~m}$ contour lines up to an altitude of $2200 \mathrm{~m}$. Higher up, no contour lines were drawn as it was quite clear from earlier studies (Paschinger, 1952; Gross and others, 1977) that the ELA of the glacier was situated between 1800 and $2000 \mathrm{~m}$ a.s.l. Steep and serrated rock areas in the uppermost part of the glacier were excluded.

\section{EQUILIBRIUM-LINE ALTITUDE}

The ELA of modern and Late-glacial glaciers in the Alps is usually calculated using an accumulation area ratio (AAR) of 0.67 . This yields reliable results for glaciers with a typical "Alpine" area-altitude distribution with large and comparatively flat surface areas in the vicinity of the equilibrium line (Gross and others, 1977; Kerschner, 1990). In the case of the Gschnitz glacier, the ELA was in the steepest part of the glacier. Therefore, it seemed reasonable to bracket it between AAR values of 0.67 and 0.60 (Fig. 5). The respective ELAs are between 1860 and $1990 \mathrm{~m}$. As a compromise, an AAR of 0.63 and an ELA of $1930 \mathrm{~m}$ are chosen for the subsequent cal- culations. The average Little Ice Age (1850) ELA in the catchment basin was at $2630 \mathrm{~m}$ (Gross and others, 1977), resulting in an ELA depression for the Gschnitz Stadial of $-700 \mathrm{~m}$ against 1850 values or about $-800 \mathrm{~m}$ against modern values.

\section{BALANGE GRADIENTS}

From the topography of the glacier and its bed, the ice-flux through selected cross-sections and balance gradients along the glacier tongue can be calculated. They are important tools for qualitative and quantitative paleoclimatic interpretations.

To calculate the ice flux, we must first know the mean velocity over a cross-section. If only ice deformation is assumed, the surface velocity $u_{\mathrm{s}}$ of an infinitely wide parallel-sided slab of ice is

$$
u_{\mathrm{s}}=2 A(\rho g \sin \alpha)^{n} \frac{h^{n+1}}{n+1}
$$

with $A$ as the temperature-dependent parameter (in this case $5 \times 10^{-15} \mathrm{kPa}^{-3} \mathrm{~s}^{-1}$; Paterson, 1994) and $n=3$ as the exponent in Glen's flow law. The mean horizontal velocity over a parabolic cross-section $u_{\mathrm{m}, \mathrm{p}}$ can then be calculated from $u_{\mathrm{s}}$ with a correction factor, which depends on the relation between glacier width and ice thickness. This was determined from table IIIA in Nye (1965, p. 677). Then, the total horizontal velocity $u_{\mathrm{t}}$ of the glacier is the mean velocity due to ice deformation $u_{\mathrm{m}, \mathrm{p}}$ plus the contribution of basal sliding $u_{\mathrm{b}}$ (Table 1). As the amount of basal sliding is unknown, scenarios were calculated with basal sliding contributing $80 \%$ and $50 \%$ of $u_{\mathrm{t}}$.

The ice flux $Q$ through a cross-section can be determined by multiplying $u_{\mathrm{t}}$ with the area of the cross-section (Fig. 2). From the difference in ice flux $\Delta Q$ between two neighbouring cross-sections and the surface area $S$ between them, net ablation can be calculated as $\Delta Q / S$, which finally has to be corrected for water equivalent. The resulting $b(z)$ curves for the glacier tongue are shown in Figure 6. For comparison, the $b(z)$ curves of various other glaciers for years with zero net balance (Kuhn, 1984) are added to Figure 6. Under the assumption of $80 \%$ basal sliding, the balance gradient is somewhere in between that of Tsentral'nyy Tuyuksu glacier (Tien Shan) and White Glacier (Canadian Arctic Archipelago), whereas for $50 \%$ basal sliding it is rather similar to that of White Glacier. If we (unrealistically) assume there was no basal sliding at all, the balance gradient is even steeper than that of Devon Ice Cap (Canadian Arctic Archipelago). Depending on the amount of basal sliding, the balance gradients $\partial b / \partial z$ on the glacier tongue between $1350 \mathrm{~m}$ and $1550 \mathrm{~m}$ a.s.l. vary between $-3.55 \mathrm{~kg} \mathrm{~m}^{-2} \mathrm{~m}^{-1}(80 \%$ basal sliding) and $-0.71 \mathrm{~kg} \mathrm{~m}^{-2} \mathrm{~m}^{-1}(0 \%$ basal sliding). These values are typical for glaciers in a cold and continental climate.

Table 1. Ice thickness $(h)$, surface slope $(\alpha)$, surface velocity $\left(u_{\mathrm{s}}\right)$, correction factor for a channel with parabolic cross-section $(f c)$, mean velocity for a parabolic cross-section $\left(u_{\mathrm{m}, \mathrm{p}}\right)$, sliding velocity for $80 \%$ basal sliding $\left(u_{\mathrm{b}}\right)$ and total velocity $\left(u_{\mathrm{t}}\right)$ for selected cross-sections. Letters a-d refer to Figures 2 and 3

\begin{tabular}{|c|c|c|c|c|c|c|c|}
\hline Cross-section & $\begin{array}{l}h \\
\mathrm{~m}\end{array}$ & $\begin{array}{c}\alpha \\
\operatorname{deg}\end{array}$ & $\begin{array}{c}u_{\mathrm{s}} \\
\mathrm{ma}^{-1}\end{array}$ & $f_{c}$ & $\begin{array}{c}u_{\mathrm{m}, \mathrm{p}} \\
\mathrm{m} \mathrm{a}^{-1}\end{array}$ & $\begin{array}{c}u_{\mathrm{b}} \\
\mathrm{ma}^{-1}\end{array}$ & $\begin{array}{c}u_{\mathrm{t}} \\
\mathrm{ma}^{-1}\end{array}$ \\
\hline $\mathrm{a}$ & 140 & 4.29 & 8.7 & 0.27 & 2.4 & 9.5 & 11.9 \\
\hline $\mathrm{b}$ & 230 & 2.99 & 21.5 & 0.24 & 5.2 & 20.7 & 25.9 \\
\hline c & 320 & 2.29 & 36.4 & 0.2 & 7.1 & 28.4 & 35.5 \\
\hline $\mathrm{d}$ & 390 & 2.15 & 66.2 & 0.14 & 9.3 & 37.1 & 46.4 \\
\hline
\end{tabular}




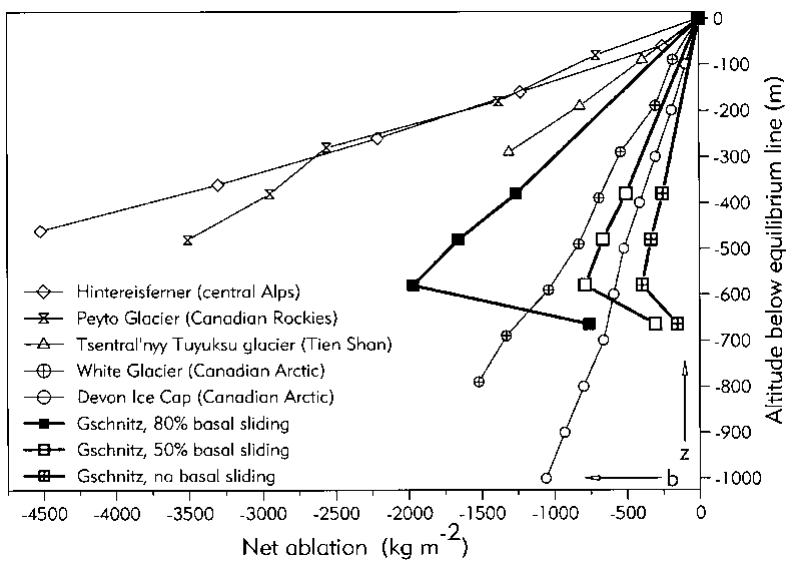

Fig. 6. Steady-state balance gradients along the glacier tongue of Gschnitz glacier and various other glaciers.

They can be cross-checked with the activity index of a stationary glacier (Kuhn and Hermann, 1990, p. 307). It relates the balance gradient $\partial b / \partial z$ with the length of the glacier tongue $X$ and the maximum velocity in the $x$ direction $u_{\mathrm{x}, \max }$ as

$$
\frac{\partial b}{\partial z}=-\rho \frac{u_{\mathrm{x}, \max }}{x}
$$

Assuming a value of $50 \mathrm{~m} \mathrm{a}^{-1}$ for $u_{\mathrm{x}, \max }$ and taking the length of the glacier tongue as $12.8 \mathrm{~km}$ (Fig. 3), $\partial b / \partial z$ is $-3.55 \mathrm{~kg} \mathrm{~m}^{-2}$ $\mathrm{m}^{-1}$, which is similar to the result obtained for $80 \%$ sliding.

\section{POSSIBLE ERRORS}

This way of calculating ice discharge and balance gradients is sensitive to various parameters. The influence of the temperature-dependent parameter $A$ is linear. The chosen value of $5 \times 10^{-15} \mathrm{kPa}^{-3} \mathrm{~s}^{-1}$ is for ice with a temperature of about $-1^{\circ} \mathrm{C}$ (Paterson, 1994). Smaller values for colder ice lead to correspondingly lower discharge rates. Values for surface slope $\alpha$ are determined as exactly as possible from the moraines, and, therefore, from topographical maps. Errors in the order of several metres can easily occur during such a procedure. As the surface slope enters the velocity equation with the third power, this may lead finally to a distortion of the $b(z)$ curves. However, the overall shape of the $b(z)$ curve is not altered significantly, even if the assumed errors are larger than necessary $(> \pm 10 \mathrm{~m})$. A systematic error in the determination of the surface slope is unlikely due to the large number of preserved moraines. Errors in the determination of the ice thickness $h$ may also occur. As the actual glacier bed remains unknown, $h$ is determined from the parabolic crosssections and only speculations can be made about the size of the errors. An error in $h$ not only influences the area of the cross-sections, but also the surface velocity because it enters the velocity equation with the fourth power. On the other hand, the effects of changes in $h$ are somewhat counterbalanced by corresponding changes in the shape factor. Changes in $h$ do not affect the surface topography, as it is largely fixed by the moraines. The results of some calculations with different values of $h( \pm 20 \mathrm{~m})$ showed fairly similar results compared to those with changes in $\alpha$. The $b(z)$ curves were distorted, but the principal shape remained the same. In any case, the balance gradients remain typical for glaciers in a cold and continental climate.
Table 2. Mean specific accumulation of Gschnitz glacier

\begin{tabular}{cc}
\hline Sliding & $\begin{array}{c}\text { Mean specific accumulation } \\
\%\end{array}$ \\
$\mathrm{~kg} \mathrm{~m}^{-2}$ \\
\hline 80 & 600 \\
67 & 360 \\
50 & 240 \\
0 & 120 \\
\hline
\end{tabular}

\section{PALEOGLIMATOLOGICAL INTERPRETATION}

This section provides some more quantitative ideas about precipitation and summer temperature during the Gschnitz Stadial. They are to some extent speculative and the figures should not be seen so much as absolute values, but rather as orders of magnitude.

By extrapolating the $b(z)$ curve towards the ELA, we can calculate the total net ablation $A_{\mathrm{n}}$ on the glacier tongue. If we assume steady-state, $A_{\mathrm{n}}$ must be balanced by total net accumulation $C_{\mathrm{n}}$. Thus we may calculate the mean specific accumulation over the accumulation area $S_{\mathrm{c}}$ as $c=A_{\mathrm{n}} / S_{\mathrm{c}}$. Even for $80 \%$ sliding, calculated values are quite low (Table 2). Only this case, which is already rather "humid" and "warm", is discussed in more detail below. All other scenarios (lower values for $A$ under the assumption of lower ice temperatures, smaller contributions of basal sliding to the velocity of the glacier) represent drier and colder conditions.

From the data in Fliri (1975) we may estimate present-day precipitation (i.e. 1931-1960) at the ELA (about $2730 \mathrm{~m}$ ) as $1700 \mathrm{~mm} \mathrm{a}^{-1}$ and summer (June-August) temperature as $3.3^{\circ} \mathrm{C}$. Similar precipitation values can be obtained from the $(P, T)$ relation of Ohmura and others (1992, p. 401). If we assume that accumulation is 1.5 times precipitation (Kuhn, 1981), it should be in the order of $2550 \mathrm{~kg} \mathrm{~m}^{-2} \mathrm{~m}^{-1}$. Assuming further that the mean specific accumulation during the Gschnitz Stadial is correct at the median altitude of the accumulation area $(2580 \mathrm{~m})$, and using an accumulation gradient of $1 \mathrm{~kg} \mathrm{~m}^{-1}$, accumulation at $2730 \mathrm{~m}$ was then about $750 \mathrm{~kg} \mathrm{~m}^{-2}$ (29\% of the present accumulation). The change in accumulation was $-1800 \mathrm{~kg} \mathrm{~m}^{-2}$. We may therefore conclude that accumulation and probably also precipitation during the Gschnitz Stadial was less than one-third of the present-day values.

Inferring temperature change is even more prone to errors. Kuhn's (1981) glacial-meteorological model should only be used with extreme caution, because $\triangle \mathrm{ELA}$ is large $(-800 \mathrm{~m})$ and the results for the summer temperature change $\delta t_{\mathrm{s}}$ are strongly influenced by the (unknown) accumulation gradients, the (unknown) duration of the ablation period, the (unknown) change of the temperature lapse rate, possible (unknown) changes of the short-wave radiation balance and the (unknown) contribution of the latent-heat flux to ablation. Despite these uncertainties, some cautious calculations show that temperatures might have been lowered in the order of -7.5 to $-11^{\circ} \mathrm{C}$.

In a different approach, various statistical $(P, T)$ models can be used. The basic assumption is that precipitation at the Gschnitz Stadial ELA was proportionally lowered like accumulation. In that case, precipitation at $1930 \mathrm{~m}$ (ELA of the Gschnitz Stadial glacier) during the Gschnitz Stadial is estimated at $400 \mathrm{~mm}$. Then we may calculate the corresponding 
summer temperature at the ELA from the $(P, T)$ models. Finally, the present-day summer temperature at $1930 \mathrm{~m}$ has to be subtracted from the Gschnitz Stadial summer temperature at the ELA to obtain $\delta t_{\mathrm{s}}$. The results are summarized in Table 3. They show that temperature was roughly $9-11^{\circ} \mathrm{C}$ lower than today with an average value of $-10.2^{\circ} \mathrm{C}$. This

Table 3. Temperature at the ELA of Gschnitz glacier ( $\mathcal{T}_{E L A}$, $G)$, present-day temperature (1931-60) at the altitude of the Gschnitz Stadial ELA ( $\left.T_{31-60}, E L A G\right)$ and changes of summer temperature $\left(\delta t_{\mathrm{s}}\right)$

\begin{tabular}{|c|c|c|c|c|}
\hline Source & $T_{E L A}, G$ & $T_{31-60}, E L A G$ & $\delta t_{\mathrm{s}}$ & Period \\
\hline $\begin{array}{l}\text { Ohmura and others } \\
\text { (1992) }\end{array}$ & -0.8 & 8.7 & -9.5 & June-August \\
\hline Kerschner (1985) & -2.4 & 8.2 & -10.6 & June-September \\
\hline $\begin{array}{l}\text { Listøl in Sissons } \\
\text { (1979) }\end{array}$ & -2.4 & 8.2 & -10.6 & June-September \\
\hline Khodakov (1975) & -1 & 9.3 & -10.3 & July-August \\
\hline Krenke (1975) & -1.1 & 8.7 & -9.8 & June-August \\
\hline
\end{tabular}

agrees surprisingly well with the results from the glacial-meteorological model. It should be kept in mind though that a summer temperature depression of about $-10^{\circ} \mathrm{C}$ is quite large and should be evaluated in further studies.

In comparison, climate during the Younger Dryas in the Alps was much warmer $\left(\delta t_{\mathrm{s}}-2.5 \mathrm{~K}\right.$ to $\left.-3 \mathrm{~K}\right)$ and more humid $(\delta P \pm 0$ to $-40 \%)$, as can be inferred from timberline and ELA fluctuations in the Austrian and Swiss Alps (e.g. Kerschner, 1985; Ivy-Ochs and others, 1996). During the Gschnitz Stadial, climate more closely resembled full glacial conditions. This strongly supports an early age for the Gschnitz Stadial.

\section{CONCLUSIONS}

From the above, we may draw some interesting conclusions for paleoclimatological research:

In valleys with simple topography (flat valley bottoms, no significant changes in the geometry of the valley), it is possible to reconstruct the topography of glacier tongues with simple glaciological models to a high degree of accuracy, if a sufficient number of moraines is preserved to calculate reliable shear stresses.

From the topography of the glacier tongue, it is possible to calculate ice flux through selected cross-sections and mass-balance gradients on the glacier tongue, which give realistic orders of magnitude. In the case of the former Gschnitz glacier, they are similar to those from glaciers in central Asia and the Canadian Arctic, thus indicating a cold and continental climate.

Under the assumption of steady-state, it is possible to estimate net accumulation, and, with some further assumptions, precipitation. Even under the assumption of $80 \%$ basal sliding, accumulation and precipitation are calculated at less than one-third of present-day values in that area.

Changes of summer temperature can be inferred with standard glacier-climate models. For earlier parts of the
Alpine Late-glacial (i.e. older than the Younger Dryas), statistical models seem to be more robust than glacialmeteorological models, which require too many assumptions. They show that summer temperature was roughly 9-11 ${ }^{\circ}$ lower than today. These results are realistic orders of magnitude.

The paleoclimatic interpretation of balance gradients is independent of non-glacial paleoclimatic information (e.g. from timberline fluctuations). Therefore, it allows quantitative paleoclimatic inferences for earlier periods of the Alpine Late-glacial, for which such information is unavailable.

\section{ACKNOWLEDGEMENTS}

We sincerely thank G. Patzelt (Institut für Hochgebirgsforschung, Innsbruck) and G. Kaser (Institut für Geographie, Innsbruck) for reading the manuscript critically and for many valuable suggestions. The comments of two reviewers (N. Hulton and A. Mackintosh) were most helpful during the final stages of the manuscript. The project was partly supported by the Swiss National Science Foundation under grant No. 21-043469.95/1. This support is most formally acknowledged.

\section{REFERENCES}

Fliri, F. 1975. Das Klima der Alpen im Raume von Tirol.Vol. 1. Innsbruck-München, Universitätsverlag Wagner. (Monographien zur Landeskunde Tirols.)

Gross, G., H. Kerschner and G. Patzelt. 1977. Methodische Untersuchungen über die Schneegrenze in alpinen Gletschergebieten. Z. Gletscherkd. Glazialgeol., 12(2), 1976, 223-251.

Haeberli, W. and U. Penz. 1985. An attempt to reconstruct glaciological and climatological characteristics of $18 \mathrm{ka} \mathrm{BP}$ ice age glaciers in and around the Swiss Alps. Z. Gletscherkd. Glazialgeol., 21, 351-361.

Haeberli, W. and J. Schweizer. 1988. Rhonegletscher 1850: eismechanische Überlegungen zu einem historischen Gletscherstand. Eidg. Tech. Hochschule, Zürich.Versuchsanst. Wasserbau, Hydrol. Glaziol. Mitt. 94, 59-70.

Ivy-Ochs, S., Ch. Schlüchter, P.W. Kubik, H.-A. Synal, J. Beer and H. Kerschner. 1996. The exposure age of an Egesen moraine at Julier Pass, Switzerland, measured with the cosmogenic radionuclides ${ }^{10} \mathrm{Be},{ }^{26} \mathrm{Al}$ and ${ }^{36}$ Cl. Eclogae Geol. Helv., 89(3), 1049-1063.

Ivy-Ochs, S., H. Kerschner, P.W. Kubik, H.-A. Synal, G. Patzelt and Ch. Schlüchter. 1997. Moraine formation in the European Alps mirrors North Atlantic Heinrich events. In Seventh Annual V.M. Goldschmidt Conference, Houston, Texas. Extended abstract. Houston, TX, Lunar and Planetary Institute, 103. (Contribution 921.)

Ivy-Ochs, S. and 6 others. 1998. The age of the Köfels event. Relative ${ }^{14} \mathrm{C}$ and cosmogenic isotope dating of an early Holocene landslide in the central Alps (Tyrol, Austria). Z. Gletscherkd. Glazialgeol., 34(1), 57-68.

Kerner von Marilaun, F. 1890. Die letzte Vergletscherung der CentralAlpen im Norden des Brenner. Mittheilungen der Kaiserlich-Königlichen Geographischen Gesellschaft in Wien, 33, 307-332.

Kerschner, H. 1985. Quantitative palaeoclimatic inferences from Late Glacial snowline, timberline and rock glacier data, Tyrolean Alps, Austria. Z. Gletscherkd. Glazialgeol., 21, 363-369.

Kerschner, H. 1986. Zum Sendersstadium im Spätglazial der nördlichen Stubaier Alpen, Tirol. Z. Geomorphol., Supplementband 61, 65-76.

Kerschner, H. 1990. Methoden der Schneegrenzbestimmung. In Liedtke, H., ed. Eiszeitforschung. Darmstadt, Wissenschaftliche Buchgesellschaft, 299-311.

Khodakov, V. G. 1975. Glaciers as water resource indicators of the glacial areas of the USSR. International Association of Hydrological Sciences Publication 104 (Symposium at Moscow 1971 - Snow and Ice), 22-29.

Krenke, A. N. 1975. Climatic conditions of present-day glaciation in Soviet Central Asia. International Association of Hydrological Sciences Publication 104 (Symposium at Moscow 1971 - Snow and Ice), 30-41.

Kuhn, M. 1981. Climate and glaciers. International Association of Hydrological Sciences Publication 131 (Symposium at Canberra 1979 - Sea Level, Ice and Climatic Change), 3-20.

Kuhn, M. 1984. Mass budget imbalances as criterion for a climatic classification of glaciers. Geogr. Ann., 66A(3), 229-238. 
Kuhn, M. and A. Herrmann. 1990. Schnee und Eis. In Baumgartner, A. and H.-J. Liebscher, eds. Allgemeine Hydrologie - Quantitative hydrologie. Berlin, Borntraeger, 271-312. (Lehrbuch der Hydrologie 1.)

Maisch, M. 1987. Zur Gletschergeschichte des alpinen Spätglazials: Analyse und Interpretation von Schneegrenzdaten. Geogr. Helv., 42(2), 63-71.

Maisch, M. and W. Haeberli. 1982. Interpretation geometrischer Parameter von Spätglazialgletschern im Gebiet Mittelbünden, Schweizer Alpen. In Gamper, M., ed. Beiträge zur Quartärforschung in der Schweiz. Zürich, Geographisches Institut der Universität, 111-126. (Physische Geographie 2.)

Mayr, F. and H. Heuberger. 1968. Type areas of Lateglacial and Postglacial deposits in Tyrol, Eastern Alps. In Richmond, G. M., ed. Glaciations of the Alps. Boulder, CO, University of Colorado. INQUA International Congress, 143-165. (Series in Earth Sciences 7.)

Nye, J. F. 1952. A comparison between the theoretical and the measured long profile of the Unteraar glacier. F. Glaciol., 2(12), 103-107.

Nye, J. F. 1965. The flow of a glacier in a channel of rectangular, elliptic or parabolic cross-section. F. Glaciol., 5(41), 661-690.

Ohmura, A., P. Kasser and M. Funk. 1992. Climate at the equilibrium line of glaciers. 7. Glaciol., 38(130), 397-411.

Paschinger, H. 1952. Die spätglazialen Gletscher des Gschnitztales. Z. Gletscherkd. Glazialgeol., 2(1), 35-57.
Paterson, W. S. B. 1994. The physics of glaciers. Third edition. Oxford, etc., Elsevier. Patzelt, G. 1975. Unterinntal-Zillertal - Pinzgau - Kitzbühel. Spät- und postglaziale Landschaftsentwicklung. In Fliri, F. and A. Leidlmair, eds. Tirolein geographischer Exkursionsführer. Innsbruck, Geographisches Institut der Universität, 309-329. (Innsbrucker Geographische Studien 2.)

Patzelt, G. 1995. 5th day: August 15; Stops 14-18. 12. Alpine traverse, Max Maisch. In Schirmer, W., ed. Quaternary field trips in central Europe. Vol. 2. München, Pfeil, 672-675.

Patzelt, G. and M. Sarnthein. 1995. Late Glacial morainal arc at Trins in the Gschnitz valley/Tyrol - "Krotenweiher" peat bog. 12. Alpine traverse, Max Maisch. In Schirmer, W., ed. Quaternary field trips in central Europe. Vol. 2. München, Pfeil, 669-670.

Penck, A. and E. Brückner. 1901/1909. Die Alpen im Eiszeitalter. Leipzig, Tauchnitz.

Pichler, A. 1859. Beiträge zur Geognosie Tirols. Zeitschrift des Museums Ferdinandeum Innsbruck, $\mathbf{3}(8)$.

Sissons, J. B. 1979. Paleoclimatic inferences from former glaciers in Scotland and the Lake District. Nature, 278, 518-521.

Van Husen, D. 1977. Zur Fazies und Stratigraphie der jungpleistozänen Ablagerungen im Trauntal (mit quartärgeologischer Karte). Jahrb. Geol. Bundesanst., 120,1-130. 